\title{
Artikel
}

\section{Overzicht van de nieuwe FIFA-regelgeving met betrekking tot het vrouwenvoetbal, coaches en intermediairs}

\author{
Roberto Branco Martins en Arne Al*
}

Vanaf 1 januari 2021 zijn in de FIFA-reglementen verschillende nieuwe bepalingen opgenomen die specifiek zien op de arbeidsvoorwaarden voor vrouwen ('speelsters') en voor coaches in het internationale voetbal. ${ }^{1}$ Daarnaast is FIFA momenteel ook bezig met het ontwerpen van nieuwe regelgeving voor intermediairs. Deze nieuwe regelgeving zal naar verwachting eind 2021 bekend worden gemaakt, waarbij inwerkingtreding is voorzien voor de zomer transfer mindom van 2022.

In dit artikel zullen de auteurs ingaan op de nieuwe regelgeving omtrent coaches en vrouwen in het internationale voetbal en zal op basis van de meest recente conceptversie van de nieuwe regelgeving voor intermediairs worden vooruitgeblikt op de naderende regelgeving met betrekking tot intermediairs.

\section{Regelgeving internationaal vrouwenvoetbal}

In oktober 2018 heeft FIFA de eerste Women's Football Strategy bekendgemaakt en geïmplementeerd. ${ }^{2}$ Het doel van FIFA met deze nieuwe strategie was om samen te werken met confederaties, bonden, clubs, speelsters, media, fans en andere belanghebbenden om het vrou-

\footnotetext{
Dr. R.C. (Roberto) Branco Martins is partner en founder bij BMDW Advocaten, docent aan de Universiteit van Amsterdam en tevens General Counsel bij Pro Agent en EFAA. Mr. A.L. (Arne) Al is advocaat bij BMDW Advocaten en Legal Content Coordinator bij DRC Database.

1. FIFA Circulair nr. 1743, 14 december 2020.

2. FIFA Women's Football Strategy, oktober 2018.
}

wenvoetbal wereldwijd te ontwikkelen en te promoten. In dit kader waren door FIFA drie hoofddoelstellingen binnen het vrouwenvoetbal vastgesteld:

1. de deelname te doen toenemen; ${ }^{3}$

2. de commerciële waarde vergroten; en

3. de basis leggen voor een effectief bestuur en regulering van een meer verfijnd ecosysteem voor vrouwenvoetbal. ${ }^{4}$

Een uitvloeisel van de derde hoofddoelstelling is onder meer de nieuwe regelgeving binnen het internationale vrouwenvoetbal. Tot voor kort bestond er nog geen regelgeving die specifiek gericht was op speelsters binnen het internationale voetbal. Wel konden speelsters in arbeidsrechtelijke geschillen reeds gebruikmaken van de geschilbeslechtingsinstanties van FIFA, ${ }^{5}$ maar specifieke regelgeving die zag op het 'vrouw zijn' ontbrak nog. Aan deze lacune is met de invoering van de nieuwe FIFA-reglementen per 1 januari 2021 een einde gekomen. Hoewel nog niet alle FIFA-regelgeving van toepassing is op het vrouwenvoetbal, ${ }^{6}$ is de invoering van de nieuwe regels een welkome toevoeging aan de reglementen en draagt zij bij aan een verdere professionalisering van het vrouwenvoetbal.

De regels zien voornamelijk op de invoering van specifieke arbeidsvoorwaarden voor beroepsspeelsters samen-

3. Het gaat hierbij om het doen toenemen van deelname van speelsters in het voetbal, zowel in de huidige competities als in regio's waar het vrouwenvoetbal nog niet of in mindere maten wordt beoefend.

4. FIFA Women's Football Strategy, oktober 2018, p. 4-8.

5. Zie bijvoorbeeld FIFA DRC 11 maart 2021, Mehler Carvalho; FIFA DRC 18 juni 2020, De Sousa en FIFA DRC 22 november 2019, Williams.

6. Uit artikel 20 RSTP volgt bijvoorbeeld expliciet dat de regels omtrent training compensation niet van toepassing zijn op het vrouwenvoetbal. Zie ook FIFA DRC 7 april 2011, nr. 411375. 
hangende met het 'vrouw zijn' en voorzien in minimumvoorwaarden met betrekking tot zwangerschap en moederschap. De wijzigingen behelzen een minimumnorm die wereldwijd moet worden toegepast, waarbij het elke aangesloten bond vrij staat om in het kader van de nationale regelgeving een strengere bescherming voor speelsters in te voeren.

Met de wijzigingen wordt in de FIFA Regulations on the Status and Transfer of Players ('FIFA RSTP') zwangerschapsverlof nu expliciet gedefinieerd als een minimumperiode van veertien weken betaald verlof, ${ }^{7}$ waarvan ten minste acht weken na de geboorte moeten worden opgenomen. ${ }^{8}$ Deze minimumperiode is in overeenstemming met de aanbeveling van de Internationale Arbeidsorganisatie in haar Maternity Protection Convention, 2000 (No. 183). Voorts is bepaald dat een club gedurende de looptijd van de arbeidsovereenkomst betaald zwangerschapsverlof moet verlenen aan een zwangere speelster ten belope van twee derde van het contractueel overeengekomen loon, ${ }^{9}$ tenzij de toepasselijke nationale wetgeving of collectieve arbeidsovereenkomst gunstiger voorwaarden oplegt. ${ }^{10}$

De kern en essentie van de nieuwe regelgeving en bescherming van de speelsters is neergelegd in het aan de RSTP nieuw toegevoegde artikel 18quater. Uit dit artikel volgt:

- dat de geldigheid van een contract niet afhankelijk mag worden gesteld van het feit of een speelster zwanger wordt, zwanger is, of gebruikmaakt van haar moederschapsrechten in het algemeen;

- wat de rechten van speelsters zijn zodra zij zwanger is. In het bijzonder heeft een zwangere speelster het recht om:

- ervoor te kiezen haar sportprestaties voort te zetten of op een andere manier arbeidsprestaties te verrichten;

- zelfstandig de begindatum van haar zwangerschapsverlof te bepalen; en

- na afloop van haar zwangerschapsverlof terug te keren tot de voetbalactiviteit.

- de verplichting voor clubs om geschikte faciliteiten te bieden aan een speelster na de bevalling om borstvoeding te geven en/of moedermelk af te kolven na haar terugkeer van zwangerschapsverlof; en

- de speciale bescherming tegen beëindiging van een contract op grond van het feit dat de speelster zwanger is of zwanger is geworden, met zwangerschapsverlof is of gebruikmaakt van rechten in verband met moederschap in het algemeen, en de aanzienlijke financiële en sportieve gevolgen voor clubs die op deze wijze handelen.

De bescherming van een zwangere speelster strekt er onder meer toe dat wanneer een arbeidsovereenkomst met een speelster wordt ontbonden terwijl ze zwanger

7. In Nederland betreft dit in totaal zestien weken, zie artikel 3:1 Wazo.

8. In Nederland is het bevallingsverlof minstens tien weken, zie artikel 3:1 lid 3 Wazo.

9. Artikel 18 lid 7 FIFA RSTP

10. In Nederland is dit $100 \%$, zie artikel $3: 7$ lid 1 jo. $3: 13$ lid 1 Wazo. is, in beginsel aangenomen wordt dat de ontbinding te maken heeft met de zwangerschap. ${ }^{11}$ Ook zijn er afwijkende bepalingen van toepassing met betrekking tot het toekennen van een vergoeding als gevolg van het door een club beëindigen van de arbeidsovereenkomst van een zwangere voetbalspeelster zonder geldige reden (just cause). Wanneer hiervan sprake is, heeft de speelster recht op een aanvullende vergoeding van zes maandsalarissen. Hiermee stelt FIFA derhalve bij voorbaat vast dat een ontbinding van de arbeidsovereenkomst van een zwangere voetbalspeelster wordt aangemerkt als een egregious circumstance, ${ }^{12}$ zoals opgenomen in artikel 17 lid 1 FIFA RSTP.

Naast de verplichting om een vergoeding te betalen, worden ook sportieve sancties opgelegd aan elke club waarvan is vastgesteld dat deze de arbeidsovereenkomst van de speelster heeft ontbonden op grond van het feit dat een speelster zwanger is of wordt, met zwangerschapsverlof is of gebruikmaakt van rechten in verband met het moederschap in het algemeen. ${ }^{13}$ De club krijgt automatisch een transferverbod opgelegd van twee volledige opeenvolgende registratieperiodes (transfer mindoms) en kan derhalve geen nieuwe speelsters in binnenof buitenland registreren. De club mag nieuwe speelsters, in binnen- of buitenland, pas inschrijven vanaf de eerstvolgende inschrijvingsperiode na de gehele duur van de desbetreffende sportieve sanctie. In het bijzonder mag de club geen gebruikmaken van de uitzondering en de voorlopige maatregelen om spelers in een eerder stadium in te schrijven. ${ }^{14}$ Daarenboven kan tezamen met het transferverbod tevens een boete aan de club worden opgelegd. ${ }^{15}$

Tot slot bevat de FIFA RSTP nu de uitzonderlijke mogelijkheid om een speelster buiten een inschrijvingsperiode in te schrijven, ${ }^{16}$ hetzij om een speelster die met zwangerschapsverlof is tijdelijk te vervangen, hetzij om een speelster na afloop van haar zwangerschapsverlof opnieuw in te schrijven. De bonden dienen hun nationale regelgeving dienovereenkomstig aan te passen, zo ook dus de KNVB. Een speelster die van zwangerschapsverlof is teruggekeerd, moet bij voorrang in aanmerking komen voor deelname aan de binnenlandse competities. Alle wijzigingen zijn bindend op nationaal niveau, tenzij gunstiger voorwaarden van toepassing zijn krachtens de nationale wetgeving, en moesten voor 1 juli 2021 ingevoerd zijn. ${ }^{17}$

\footnotetext{
Artikel 18quater lid 2 onder a) FIFA RSTP.

Verzwarende omstandigheden.

Artikel 18quater lid 3 onder b) FIFA RSTP

Zie artikel 6 lid 1 onder a) FIFA RSTP.

Artikel 18quater lid 2 onder c) FIFA RSTP.

Artikel 6 lid 1 FIFA RSTP.

7. In Nederland kennen we het opzeggingsverbod dat geldt vanaf het vermoedelijke begin van de zwangerschap en duurt tot zes weken na de periode waarop de werkneemster recht heeft op ziekengeld in verband met de zwangerschap, zie artikel 7:760 lid 2 BW.
} 


\section{Vrouwenvoetbal in Nederland}

Wanneer we kijken naar de regelgeving van het vrouwenvoetbal in Nederland specifiek, dan zijn hier verschillende punten waar de KNVB in onze optiek nog verder kan werken aan het professionaliseren van de sport. De meeste vrouwen die actief zijn in de eredivisie, zijn momenteel nog effectief als amateur geregistreerd en krijgen enkel een onkosten- en/of reiskostenvergoeding van de club. De clubs die deelnemen aan de vrouwen eredivisie worden door de KNVB als amateurverenigingen aangemerkt wat betreft overschrijving. ${ }^{18}$ Hoewel de meeste vrouwen in de eredivisie effectief als amateur geregistreerd zijn, worden verschillende speelsters belemmerd in hun keuze om naar een andere club in de eredivisie overgeschreven te worden. ${ }^{19}$ Verschillende eredivisieclubs hebben onderling afspraken gemaakt met betrekking tot de overgang van speelsters die actief zijn in de vrouwen eredivisie. Deze onderlinge afspraken zijn vastgelegd dan wel overeengekomen in een zogenoemde 'gentlemen's agreement'. Wat deze afspraken exact zijn, is onduidelijk, maar in grote lijnen houden de afspraken in dat indien een eredivisieclub met een speelster een 'overeenkomst' heeft (lees: afspraken heeft gemaakt met betrekking tot bijvoorbeeld een onkostenvergoeding en er aldus geen sprake is van een arbeidsovereenkomst dan wel van een geregistreerd contract bij de KNVB), clubs eerst toestemming van elkaar dienen te verkrijgen alvorens met een speelster een gesprek aan te mogen gaan, ofwel dat clubs bij voorbaat te kennen geven geen interesse in de betreffende speelster te hebben (ook al is het tegendeel het geval). De clubs trachten op basis van deze onderlinge afspraken zichzelf meer zekerheid te verschaffen en speelsters langer aan zich te binden zonder een arbeidsovereenkomst met hen aan te hoeven gaan. De KNVB is van deze afspraken op de hoogte maar heeft tot op heden nog geen actieve rol aangenomen om deze voor de speelsters kwalijke situatie aan te pakken. Hoewel sec gezien de clubs hiermee niet in strijd handelen met de reglementen van de KNVB, wordt hiermee wel de verdere professionalisering van het vrouwenvoetbal tegengehouden. Doordat de onderlinge afspraken de overschrijving van speelsters naar andere eredivisieclubs in grote mate belemmert en derhalve de club minder snel de speelster zal 'kwijtraken' aan een concurrent, vervalt voor de betreffende clubs de noodzaak om een speelster aan zich te binden door middel van het sluiten van een arbeidsovereenkomst. De club bespaart hier kosten mee, maar de speelster is genoodzaakt om haar inkomsten op een andere manier te verwerven en zal zich aldus niet volle-

18. Artikel 1 lid 3 Reglement Overschrijvingsbepalingen Amateurvoetbal. Zie ook artikel 2 lid 1 Reglement Wedstrijden Vrouwen KNVB.

19. Zie bijvoorbeeld Matthijs Snepvangers (Omroep West), Van ADO-vrouwen naar mannen van DUNO: 'Wel leuk dat er een ding van wordt gemaakt', 2 juli 2021, geraadpleegd via: https://www.omroepwest.nl/ sport/4416541/van-ado-vrouwen-naar-mannen-van-duno-wel-leukdat-er-een-ding-van-wordt-gemaakt. dig op haar sport kunnen richten. Het behoeft geen toelichting dat het voorgaande de kwaliteit en de professionalisering van het nationale vrouwenvoetbal niet ten goede komt.

\section{Regelgeving coaches}

Hoewel coaches belangrijke actoren zijn binnen de voetbalgemeenschap en een vitale rol spelen in de ontwikkeling van het spel en de spelers, waren er in de reglementen van FIFA nog geen specifieke bepalingen opgenomen die de arbeidsverhouding van coaches reguleerden. Het ontbreken van specifieke regelgeving met betrekking tot coaches resulteerde in enige rechtsonzekerheid. Daarbij volgde uit de jurisprudentie van het Court of Arbitration for Sport ('CAS') dat de FIFA RSTP in zijn algemeenheid niet direct van toepassing was op geschillen met betrekking tot coaches. ${ }^{20}$ Voor coaches bestond wel reeds de mogelijkheid om hun arbeidsrechtelijke geschillen met clubs of een bond aan de FIFA Players' Status Committee ('FIFA PSC') voor te leggen, maar onderliggende regelgeving waarop een coach zich kon beroepen ontbrak nog.

Op 14 december 2020 kondigde FIFA echter ook specifieke regelgeving gericht op coaches aan. ${ }^{21}$ De betreffende regelgeving is opgenomen in de nieuw toegevoegde Annex 8 van de FIFA RSTP. Door middel van het minimumregelgevingskader voor voetbalcoaches tracht FIFA rechtszekerheid te scheppen met betrekking tot arbeidsverhoudingen tussen coaches en hun club of bond. Daarnaast wordt het werk van de bevoegde FIFA-organen vergemakkelijkt bij de beslechting van arbeidsgerelateerde geschillen van coaches. Met de nieuwe regelgeving voor coaches wordt in grote lijnen eenzelfde rechtszekerheid en duidelijkheid geboden als aan contractspelers in het internationale voetbal. In de nieuwe regelgeving is de definitie van 'coach' opgenomen in de FIFA RSTP, welke luidt:

'Coach: an individual employed in a football-specific occupation by a professional club or association whose:

i. employment duties consist of one or more of the following: training and coaching players, selecting players for matches and competitions, making tactical choices during matches and competitions; and/or

20. CAS 2015/A/4161 (Vladimir Sliskovic v. Qingdao Zhongneng Football Club), award van 28 april 2016 en CAS 2009/A/1758 (Theo Bücker v. Ismailia SC), award van 29 oktober 2009. Echter, uit andere jurisprudentie van het CAS volgt anderzijds ook weer dat contractuele geschillen tussen coaches en clubs gelijk worden behandeld als die tussen spelers en clubs, zie bijvoorbeeld CAS 2007/A/1322 (Giuseppe Giannini et al. v. S.C. Fotebal Club 2005 S.A.), award van 15 april 2008. Aan deze rechtsonzekerheid is met de invoering van de nieuwe reglementen een einde gekomen

21. FIFA Circulair nr. 1743, 14 december 2020. 
ii. employment requires the holding of a coaching licence in accordance with a domestic or continental licensing regulation. ${ }^{22}$

De definitie is voornamelijk van belang met het oog op de bevoegdheidsvraag van de FIFA PSC. De definitie van coach in de FIFA RSTP is een codificatie van de jurisprudentie van de FIFA PSC. Uit de betreffende jurisprudentie volgde dat het niet altijd evident was welke personen binnen de club als 'coach' door de FIFA PSC worden aangemerkt. Uit de jurisprudentie volgde onder meer dat fysiek trainers, ${ }^{23}$ hersteltrainers, masseurs, enzovoort, ${ }^{24}$ niet door de FIFA PSC werden aangemerkt als 'coach'. ${ }^{25}$ Vanwege de definitie van 'coach' in de nieuwe reglementen, is het niet te verwachten dat de FIFA PSC hier nu anders over zal oordelen.

In de arbeidsovereenkomst hoeft niet per definitie de werknemer als coach benoemd te worden voor de FIFA PSC om haar bevoegdheid aan te nemen. Indien bijvoorbeeld in de arbeidsovereenkomst verwezen werd naar een 'official' was de FIFA PSC, mede in het licht van de taakomschrijving van de 'official', van mening dat er sprake was van een coach zoals bedoeld in artikel 22 lid c FIFA RSTP. ${ }^{26}$ Bij de totstandkoming van de arbeidsovereenkomst met een coach is het derhalve van belang om de betreffende definitie in ogenschouw te nemen en in de overeenkomst voldoende aanknopingspunten op te nemen op basis waarvan de FIFA PSC zich bevoegd zal verklaren.

Zoals gezegd wordt met de nieuwe regelgeving voor coaches in grote lijnen eenzelfde rechtszekerheid en duidelijkheid geboden als aan contractspelers in het internationale voetbal. Veel van de bepalingen voor coaches zijn namelijk vergelijkbaar of overeenkomstig met de bepalingen die van toepassing zijn op spelers. Voor de toepasselijkheid van de betreffende regelgeving is het onder meer van belang dat er sprake is van een schriftelijke overeenkomst en dat de coach meer dient te verdienen dan een onkostenvergoeding. ${ }^{27}$ Voor de totstandkoming van de arbeidsovereenkomst van de coach is bepaald dat deze niet afhankelijk gesteld mag worden van het verkrijgen van een werk- of verblijfsvergunning, licenties en/of andere administratieve vereisten. ${ }^{28} \mathrm{Uit}$ de jurisprudentie volgt verder dat tegenvallende presta-

22. FIFA RSTP februari 021 editie, definities onder 28.

23. Zie FIFA PSC 26 januari 2016, nr. 01160677; FIFA PSC 22 november 2016, nr. 11160838 en FIFA PSC 27 juli 2016, nr. 07160832.

24. FIFA PSC 26 maart 2015, nr. 0315451.

25. Assistent trainers en keeperstrainers vallen in beginsel wel onder de definitie, zie FIFA PSC 26 januari 2021, Orofino en FIFA PSC 26 maart 2015, nr. 0318152

26. FIFA PSC 11 juli 2017, nr. 07170250. Zie ook als voorbeeld CAS 2010/A/2108 (Jamaica FF V. FIFA \& V. Milutinovic), award van 2 februari 2011.

27. Artikel 1 lid 2 onder a) jo. artikel 2 lid 1 Annex 8 FIFA RSTP. De betreffende bepaling is vergelijkbaar met artikel 2 lid 2 FIFA RSTP. Zie jurisprudentie hieromtrent CAS 2015/A/4161 (Vladimir Sliskovic v. Qingdao Zhongneng Football (lub), award van 28 april 2016

28. Artikel 2 lid 4 Annex 8 FIFA RSTP. Vergelijk met artikel 18 lid 4 FIFA RSTP. ties ${ }^{29}$ het niet verkrijgen van een visum of werkvergunning ${ }^{30}$ of ziekte ${ }^{31}$ geen geldige redenen zijn voor het ontbinden van de arbeidsovereenkomst van de coach.

Ook met betrekking tot openstaande betalingen is voor coaches een overeenkomstige bepaling met die van artikel 12bis FIFA RSTP opgenomen, welke voor spelers heeft te gelden. Wanneer een club zonder geldige reden verzuimt om binnen dertig dagen aan een betaalverplichting te voldoen, is de coach gerechtigd om zich tot de FIFA PSC te wenden en de vordering inclusief sportieve sancties af te dwingen. ${ }^{32}$ Daarnaast geldt voor coaches ook een overeenkomstige bepaling met die van artikel 14bis FIFA RSTP. ${ }^{33}$ Ook coaches hebben op basis van de nieuwe regelgeving de mogelijkheid om de arbeidsovereenkomst met een geldige reden te ontbinden indien een bedrag van minimaal twee maandsalarissen niet door de club is betaald en de coach de club een schriftelijke aanmaning heeft gestuurd waarin de club een termijn van vijftien dagen wordt gegeven om volledig te voldoen aan zijn financiële verplichtingen voortvloeiende uit de arbeidsovereenkomst. ${ }^{34}$

Naast deze nieuwe bepalingen zal de jurisprudentie van de FIFA PSC inzake de bescherming van de contractstabiliteit van coaches door de FIFA PSC naar verwachting worden gehandhaafd. ${ }^{35}$ Daarbij merken wij op dat, zoals reeds aangegeven, tegenvallende prestaties, ${ }^{36}$ het niet verkrijgen van een visum of werkvergunning ${ }^{37}$ of ziekte $^{38}$ geen geldige redenen zijn voor het ontbinden van de arbeidsovereenkomst van de coach.

Wat betreft het vaststellen van de vergoeding die betaald dient te worden na het ontbinden van de arbeidsovereenkomst is door FIFA tevens een overeenkomstige bepaling opgenomen zoals die voor spelers te gelden heeft. ${ }^{39}$ Wanneer een club de arbeidsovereenkomst met een coach zonder geldige reden ontbindt, dient de club

29. FIFA PSC 23 maart 2021, Assis de Lira; FIFA PSC 23 maart 2021, De Lira; FIFA PSC 26 januari 2021, Dudamel Ochoa; FIFA PSC 12 januari 2021, nr. 01210622; FIFA PSC 11 juli 2017, nr. 15-01600 (ongepubliceerd) en FIFA PSC 15 juni 2016, nr. 0616331

30. Zie bijvoorbeeld FIFA PSC 5 juni 2013, nr. 0613864.

31. FIFA PSC 28 augustus 2013, nr. 08130097.

32. Artikel 7 Annex 8 FIFA RSTP.

33. Zie in dit kader F.M. de Weger \& A.L. Al, Termination of employment contracts due to outstanding salaries, Football Legal juni 2021, p. 24-34. Zoals bij spelers artikel 14bis RSTP een codificatie is van de jurisprudentie van de FIFA DRC, is artikel 5 lid 1 Annex 8 FIFA RSTP tevens een codificatie van de jurisprudentie van de FIFA PSC, zie bijvoorbeeld FIFA PSC 20 november 2020, Da Cruz Vicente. Zie ook CAS 2007/A/1322 (Giuseppe Giannini et al. v. S.C. Fotebal Club 2005 S.A.), award van 15 april 2008.

34. Artikel 5 lid 1 Annex 8 FIFA RSTP.

35. Contractuele stabiliteit ligt namelijk aan de basis van een efficiënt systeem en houdt onder meer in dat contracten nagekomen dienen te worden (pacta sunt servanda) en gaat eenzijdige contractuele schendingen en opzeggingen tegen, wat de integriteit van de sport en de voetbalcompetities ten goede komt.

36. FIFA PSC 23 maart 2021, Assis de Lira; FIFA PSC 23 maart 2021, De Lira; FIFA PSC 26 januari 2021, Dudamel Ochoa; FIFA PSC 12 januari 2021, nr. 01210622; FIFA PSC 11 juli 2017, nr. 15-01600 (ongepubliceerd) en FIFA PSC 15 juni 2016, nr. 0616331

37. Zie bijvoorbeeld FIFA PSC 5 juni 2013, nr. 0613864.

38. FIFA PSC 28 augustus 2013, nr. 08130097.

39. Vergelijk artikel 6 Annex 8 met artikel 17 FIFA RSTP. Uit jurisprudentie van het CAS volgde onder meer dat artikel 17 FIFA RSTP niet van toepassing was op geschillen met coaches, zie CAS 2008/A/1464 (Futebol 
in beginsel de restwaarde van de arbeidsovereenkomst als schadevergoeding aan de coach te voldoen. Let wel, de schadevergoeding kan gereduceerd worden indien de coach gedurende de initiële looptijd van de ontbonden arbeidsovereenkomst reeds nieuwe inkomsten heeft verworven welke voortvloeien uit een arbeidsovereenkomst met een andere club of voetbalbond. ${ }^{40}$

Ten slotte is voor de consequenties van het niet nakomen van een vonnis van de FIFA PSC, binnen de gebruikelijke 45 dagen-termijn, een overeenkomstige bepaling opgenomen met die van artikel 24bis FIFA RSTP. ${ }^{41}$ FIFA heeft derhalve de mogelijkheid om direct sportieve sancties op te leggen indien een vonnis niet binnen de 45 dagen wordt nagekomen.

\section{Regelgeving intermediairs}

FIFA heeft zich ook gedwongen gevoeld om, in het kielzog van de wijzigingen van de RSTP, de regels rond intermediairs aan te passen. De nieuwe regelgeving met betrekking tot intermediairs vloeide voort vanuit de visie van FIFA dat het transfersysteem moest worden aangepast. Deze visie is niet geheel op eigen initiatief tot stand gekomen.

De wereldspelersvakbond FIFPRo maakte in 2015 al duidelijk dat het systeem van transfers nadelig was voor spelers vanuit het perspectief van de belemmering van de vrijheid van de speler en het onderstrepen van de superieure houding van clubs in relatie tot de werknemers, de spelers. ${ }^{42}$ FIFA ervaarde de druk vanuit FIFPRo, en wellicht de mogelijke dreiging van een 'nieuwe Bosman'. ${ }^{43}$ Een gevolg van deze ontwikkeling was dat FIFA een Transfer System Task Force oprichtte die zich bezig ging houden met de herziening van het transfersysteem. Deze Task Force, praktisch geleid door FIFA's interne juristen, opereert op basis van input van de deelnemers aan het Football Stakeholders Committee en rapporteert weer terug aan dit comité. Het FIFA Executive Committee voert een laatste controle uit, waarna de finale versie bekrachtigd kan worden door de president en secretaris-generaal. ${ }^{44}$

Vanuit verschillende agentengroeperingen is kritiek geuit op de wijze waarop FIFA de voetbalwereld heeft geconsulteerd met betrekking tot de hervorming van het transfersysteem, en dan met name vanwege het feit dat consultatie van agenten slechts in de marge heeft plaats-

Clube do Porto v. J. \& CAS 2008/A/1467 J. v. Futebol Clube do Porto), award van 3 december 2008.

40. Artikel 6 lid 2 sub b) FIFA RSTP.

41. Zie artikel 8 Annex 8 FIFA RSTP.

42. Een uittreksel van de klacht kan worden gevonden op: https:// www.europarl.europa.eu/doceo/document//E-8-2017-005338_ EN.html.

43. HvJ EU 15 december 1995, zaak C-415/93, ECLI:EU:C:1995:293 (URBSFA/Jean-Marc Bosman).

44. https://www.fifa.com/about-fifa/organisation/committees. gevonden en niet als onderdeel van de Task Force en/of als onderdeel van het Stakeholders Committee. ${ }^{45}$

Als onderdeel van het proces om het transfersysteem te hervormen zouden ook de FIFA Regulations on Working with Intermediaries ('RWWI') aangepast worden. Op deze manier kwam FIFA tegemoet aan de kritiek die vanuit de markt geuit was op de RWWI die FIFA vrij plotseling in 2015 invoerde. Het baanbrekende van de RWWI was met name het einde van de licentieplicht voor spelersmakelaars en het loslaten van regulering van het beroep versus regulering van de transactie. De regulering verschoof van het centrale niveau van FIFA naar het niveau van de nationale bonden. Elke bond diende een eigen reglement te implementeren en dit leidde tot praktische belemmeringen in de dienstverlening door agenten. $^{46}$

$\mathrm{Na}$ een lang proces van onderhandelingen presenteerde FIFA in november 2020 de contouren van het nieuwe systeem. Op het moment van schrijven van dit artikel bevindt dit proces zich in de derde en laatste consultatiefase en hoopt FIFA voor het einde van 2021 het nieuwe reglement te presenteren. Het is nog onduidelijk wat de definitieve versie van het nieuwe reglement gaat worden. Duidelijk is wel dat de reikwijdte van het ontwerp dat nu op tafel ligt opnieuw slechts ziet op arbeidsbemiddeling en het onderhandelen van arbeidscontracten. Activiteiten die niet in deze context vallen worden niet gereguleerd door de reglementen. Echter, FIFA lijkt wel te gaan verlangen dat openheid gegeven dient te worden over andere activiteiten opdat een controle op de verdiensten van agenten en van geldstromen in het algemeen mogelijk wordt gemaakt. ${ }^{47}$ De reglementen bevatten minimale voorwaarden die door de nationale bonden moeten worden overgenomen. Waar nationaal recht een andere uitwerking heeft op de situatie die FIFA voorschrijft, zal nationaal recht voor gaan. Hieronder gaan wij in op hoofdlijnen van het nieuwe reglement, waarbij zij opgemerkt dat deze bijdrage zich niet leent voor een (te) gedetailleerde beschrijving.

\section{Licentiesysteem}

Als gevolg van de nieuwe reglementen zal FIFA opnieuw een licentiesysteem introduceren en wordt de spelersmakelaar getypeerd als 'Football Agent'. Een aspirant Football Agent dient een examen af te leggen en zodra de licentie behaald is, dient er een permanente educatie gevolgd te worden. Een dergelijk systeem is

45. FIFA heeft bijvoorbeeld de European Football Agents Association (EFAA) niet officieel gehoord en heeft als agenten de kleinere organisaties PROFAA en een conglomeraat van Zuid-Amerikaanse agenten toegelaten tot het overleg. Vanuit EFAA en tevens vanuit de splintergroepering van 'superagenten', waarin tevens spelers worden vertegenwoordigd, The Football Forum, is met name kritiek geuit vanwege de ogenschijnlijke schending van het mededingingsrecht in relatie tot de wens om tot een 'cap' op commissies te komen.

46. R.C. Branco Martins, Intermediairs in de voetbalwereld: verleden, heden... toekomst?, in: Capita Sportrecht, Oud-Turnhout/'s-Hertogenbosch: Gompel\&Svacina 2020, p. 308.

47. De grondslag voor informatie met betrekking tot nieuwe reglementen volgt uit (informele) gesprekken en ontwerpstukken waardoor het verwijzen naar algemeen toegankelijke bronnen niet mogelijk is en in het verdere verloop van deze bijdrage ook achterwege zal worden gelaten. 
vergelijkbaar met het 'puntensysteem' van advocaten. Intermediairs die voor 2015 reeds een FIFA-licentie hadden behaald hoeven niet opnieuw examen te doen maar dienen wel in het eerste jaar van de permanente educatie twee keer het aantal punten te behalen die gelden voor de net geslaagde Football Agents.

\section{Clearing house}

De betalingen aan intermediairs worden gedaan via een zogenoemde 'clearing house'. Dit is een systeem waarbij de betalingen via een centraal punt gedistribueerd worden. De betalingen en de begunstigden worden geopenbaard om zodoende transparantie te garanderen. FIFA voorziet dat de oprichting van een dergelijk clearing house-systeem niet synchroon zal kunnen lopen met de inwerkingtreding van de reglementen, dus zal er sprake zijn van een overgangsfase bij de aanvang van de inwerkingtreding. Tot de invoering van het clearing house-systeem worden de betaalstromen nog op 'de oude manier' gedocumenteerd. Ook op andere fronten zullen soortgelijke wijzigingen worden ingevoerd onder aanvoering van de Football Stakeholders Committee. Zo heeft FIFA in aanloop naar het nieuwe systeem met betrekking tot internationale opleidingsvergoedingen reeds enkele wijzigingen doorgevoerd. ${ }^{48}$

FIFA eist totale transparantie inzake financiële transacties. Het streven van FIFA is om elke transactie te publiceren en algemeen toegankelijk te maken. Het is nog onduidelijk welke gegevens daarbij openbaar gemaakt worden, maar het lijkt voor de hand te liggen dat (inter)nationale wetgeving op het gebied van privacy en gegevensbescherming strenge eisen stelt aan het openbaar maken van gevoelige informatie. Het ligt voor de hand dat geen enkele Football Agent zit te wachten op de publicatie van zijn verdiensten; puur en alleen al op basis van veiligheidsoverwegingen.

\section{Beroepsaansprakelijkheidsverzekering}

Daarnaast is de introductie van een verplichte beroepsaansprakelijkheidsverzekering een noviteit. De verzekering eist een verzekerd bedrag aan risico van minimaal CHF 100.000. Boven dat minimum geldt dat het $10 \%$ van de verwachte omzet van de Football Agent dient te bedragen.

\section{Contractstabiliteit}

Ook in de regelgeving met betrekking tot intermediairs is FIFA strikt met de wens om contractstabiliteit zo veel mogelijk te garanderen. In dit kader had FIFA in eerste instantie in de eerste conceptreglementen opgenomen dat een Football Agent hoofdelijk aansprakelijk zou zijn voor het bedrag aan schadevergoeding indien een speler eenzijdig zonder geldige reden een arbeidsovereenkomst met zijn club verbreekt. Indien de speler een Football Agent heeft op het moment dat hij zijn arbeidsovereenkomst eenzijdig zonder geldige reden verbreekt, werd de Football Agent geacht te hebben meegewerkt aan die onrechtmatige contractbreuk en derhalve in beginsel mede aansprakelijk te zijn, tenzij de Football Agent het

48. FIFA Circulair nr. 1752, 26 maart 2021 tegendeel kon bewijzen. Vergelijkbaar met de aansprakelijkheid van clubs, zoals die heden ten dage in de huidige RSTP is opgenomen. In een later ontwerp van het reglement is deze bepaling komen te vervallen.

Met het oog op het behoud van contractstabiliteit wordt in de meest recente versie van de nieuwe reglementen wel een begrenzing van de commissie geintroduceerd. Een Football Agent heeft als verdienmodel mede de mogelijkheid een percentage te ontvangen over het salaris van de speler, waarbij de berekening plaatsvindt op basis van het jaarsalaris van de speler. Indien de Football Agent namens de speler werkt, kan de Football Agent een maximale vergoeding ontvangen van 3\% over het bruto jaarsalaris van de speler. De mogelijkheid van dubbele vertegenwoordiging bestaat slechts wanneer een Football Agent namens een speler optreedt die een contract met een club aangaat en dan in combinatie met het mogen vertegenwoordigen van de aankopende club. Bij een dergelijke dubbele vertegenwoordiging mag een agent tevens van de verkopende club een percentage van $3 \%$ over het jaarsalaris van de speler factureren. Indien de agent voor de aankopende club werkt, geldt het maximum van 3\%. Bij een 'uitgaande transfer' en eraan gekoppelde contractonderhandelingen, ligt de 'cap' ingeval van een dubbele vertegenwoordiging aldus op $6 \%$ van het bruto basis jaarsalaris van de speler. Indien een speler een bruto jaarsalaris heeft van minder dan USD 200.000, is de club gerechtigd om namens de speler te betalen. In principe geldt wel 'de afnemer van de dienst betaalt'; met de uitzondering van de USD 200.000-grens.

De Football Agent mag geen dubbele vertegenwoordiging toepassen wanneer de Football Agent optreedt voor de verkopende club. In voornoemd geval geldt een maximumcommissie van $10 \%$ over de transfersom die de verkopende club ontvangt. In Nederland geldt overigens de Wet allocatie arbeidskrachten door intermediairs (Waadi) die maakt dat een werkzoekende nimmer dient te betalen voor de verleende diensten betreffende arbeidsbemiddeling. Hier staat het reglement van FIFA dus haaks op de eisen vanuit de Nederlandse wetgeving en zal derhalve de Nederlandse wetgeving prevaleren.

De reglementen geven geen begrenzing voor het ontvangen van een vergoeding in de vorm van vaste bedragen ('fixed fee') en declaraties op basis van uurtarieven. Het lijkt alsof de ratio achter deze bepaling ligt in het willen tegengaan van speculatie betreffende waardestijgingen van spelers. De gedachte vanuit FIFA is dat een percentage speculatie in de hand werkt en een fixed fee niet, of minder.

\section{Geschilbeslechting}

In het geval van geschillen met een internationale dimensie dient een Football Agent zich te wenden tot een speciaal voor Football Agents te creëren geschilbeslechtingsinstantie binnen FIFA. ${ }^{49}$ De contouren van een dergelijk tribunaal zijn nog niet bekend. Aan dit tri-

49. Uit de reglementen volgt dat een geschil een internationale dimensie heeft indien op het moment van de transactie de speler of coach en de agent een verschillende nationaliteit hebben of indien de betrokken club 
bunaal, bestaande uit een panel van arbiters, kunnen partijen hun onderlinge geschil voorleggen. Op basis van de reglementen zullen er ook verschillende sancties opgelegd kunnen worden aan clubs, spelers en Football Agents.

\section{Minors}

Zodra minderjarige spelers in hun respectievelijke land een arbeidsovereenkomst mogen tekenen, kunnen ze begeleid worden door Football Agents. Een noviteit is dat Football Agents ook voor deze activiteiten betaald mogen worden vanaf het moment dat een speler een arbeidsovereenkomst mag tekenen in het land waar de registratie plaats gaat vinden.

\section{Conclusie}

De invoering van de nieuwe regelgeving in het internationale voetbal met betrekking tot het vrouwenvoetbal en de coaches zorgt voor meer rechtszekerheid, harmonisatie en contractstabiliteit en draagt bij aan een verdere professionalisering van het internationale voetbal.

De nieuwe regelgeving met betrekking tot het internationale vrouwenvoetbal ziet voornamelijk op de invoering van specifieke arbeidsvoorwaarden voor beroepsspeelsters, samenhangende met het 'vrouw zijn' en het voorzien in minimumvoorwaarden met betrekking tot zwangerschap en moederschap. Daarmee biedt FIFA speelsters aanvullende bescherming, wat de professionalisering van het internationale vrouwenvoetbal en de rechtspositie van speelsters ten goede zal komen.

De nieuwe regelgeving specifiek gericht op coaches zorgt voor een grotere rechtszekerheid inzake internationale arbeidsrechtelijke geschillen tussen coaches en hun club of bond. De regels zijn in grote lijnen overeenkomstig met de regels die gelden voor spelers in internationale arbeidsrechtelijke geschillen en creëren derhalve transparantie en rechtszekerheid voor alle actoren en zal uiteindelijk het voetbal in zijn geheel ten goede komen.

Dat er voor intermediairs nieuwe regelgeving aanstaande is, staat zo goed als vast. Echter, de vraag blijft in hoeverre een nieuw reglement daadwerkelijk voor een wereldwijde harmonie zal zorgen. Immers, nationale wetgeving heeft altijd voorrang boven de FIFA-reglementen en daarmee kan nationale wetgeving een uniforme grensoverschrijdende implementatie in de weg staan. Daarbij dient tevens de kanttekening gemaakt te worden dat op het moment van schrijven de derde consultatieronde van FIFA in gang is gezet. Inmiddels is er veel kritiek geuit op de reglementen en is de dreiging van een juridische strijd, op basis van een schending van het mededingingsrecht, vanwege de invoering van de 'caps' op commissies, realistisch. Het losbranden van een felle juridische strijd doemt op aan de horizon. Deze ontwikkelingen maken dat het nog immer relevant is om alternatieve vormen van regulering te onderzoeken en voor spelersmakelaars om zich zeer goed te vergewissen van de vigerende regelgeving alvorens tot dienstverlening in een bepaald land over te gaan. De hectiek en het 'adhoc'-karakter van de markt bemoeilijkt echter een dergelijke houding. 